\title{
Reasons, Consequences and Solutions to Anti-Business Logic Behavior of State-Owned Enterprises Controllers
}

\author{
Nana Zhang1,2 \\ ${ }^{1}$ Business School, Beijing Normal University, Beijing, China \\ ${ }^{2}$ Etonhouse International Education Group, Beijing, China \\ Email: nichao2011@126.com
}

How to cite this paper: Zhang, N.N. (2018) Reasons, Consequences and Solutions to Anti-Business Logic Behavior of State-Owned Enterprises Controllers. American Journal of Industrial and Business Management, 8, 1770-1776.

https://doi.org/10.4236/ajibm.2018.88119

Received: July 18, 2018

Accepted: August 17, 2018

Published: August 20, 2018

Copyright $\odot 2018$ by author and Scientific Research Publishing Inc. This work is licensed under the Creative Commons Attribution International License (CC BY 4.0).

http://creativecommons.org/licenses/by/4.0/

\begin{abstract}
Focusing on the anti-business logic behavior of state-owned enterprises controllers, this paper finds that the behavior is characterized by lack of cost constraints, control of commodity prices to make it lower than market equilibrium price, stressing on scale while neglecting efficiency, etc., which causes consequences of overcapacity in some state-owned enterprises, zombie enterprises, the loss of state-owned assets, financial burdens for the state, and unequal market status for private enterprises. Finally, the paper puts forward effective solutions.
\end{abstract}

\section{Keywords}

State-Owned Enterprises Controllers, Incentive Mechanism, Anti-Corruption

\section{Introduction}

As a core component of China's national economy, state-owned enterprises play an important role in China's economic development. How to give full play to the core value of state-owned enterprises? It depends on the heads of state-owned enterprises. State-owned enterprise controllers refer to those who actually control the state-owned enterprises behaviors. In different state-owned enterprises, the controllers are given different names, such as the chairman, president, and factory director. Generally the basic business logic of enterprise is to maximize profit [1]. However, in some state-owned enterprises in China, controllers are manifesting anti-business logic behavior, which does no good in improving the efficiency of state-owned enterprises, but causes problems of internal corruption, loss of state assets and brain drain. The anti-business logic behavior refers to that 
as the head of an enterprise, he does not actively pursue profits, but pursues other goals. The $19^{\text {th }}$ National Congress report points out, "We must to adhere to quality first, efficiency first, with supply-side structural reform as the main line, promote quality change, efficiency change and driving force change in economic development, and improve total factor productivity." This goal cannot be achieved without the efforts of state-owned enterprises controllers. It is necessary to face up to the problem and put forward effective countermeasures to encourage entrepreneurial spirit of state-owned enterprises controllers and promote the return of enterprises nature: profit maximization.

\section{Manifestation of the Anti-Business Logic Behavior of State-Owned Enterprises Controllers}

1) Lack of cost constraints. Cost control determines whether enterprises' profit maximization can be achieved. State-owned enterprise controllers often lack cost constraint management in business. Main reasons are as follows: First, costs increase due to severe corruption. There are two types of corruption within state-owned enterprises. The first is the exclusive corruption by leaders. State-owned enterprise executives use their powers to misappropriate state-owned assets through large-scale kickbacks, taking bribes or public consumption, which results in high cost of state-owned enterprises; the second is corruption through employee welfare. While using various means to gain advantages, in order to pacify the resentment of employees, calm the turmoil and obtain stability, state-owned enterprise controllers often increase or raise in disguised form the income of employees in "reasonable" ways to gain support and win over minds. Second, "reverse elimination" runs out of cost. In essence, competition of modern enterprise is competition of core competitiveness: talents. Many state-owned enterprises are overstaffed. The administrative power determines everything, resulting in reverse elimination, mutual restraint, mutual interference and inefficiency. As a result, many talented young who are unable to realize personal values have to hop to private enterprises to seek a new future. Third, blind decision-making regardless of cost. In management and operation, decision-making is the most important. Most state-owned enterprise executives, directly appointed by the higher-level administrative department, are unfamiliar with enterprise management. The implementation of democratic concentration results in mutually making excuses and buck-passing in "democracy" and wrong decision-making in "concentration" due to lack of market management ability, sense of responsibility, and failure in removing interference of the interests of all parties.

2) Lowering products prices. State-owned enterprise controllers harm the state interests by lowering products prices. First, lowering the price of resource-based products. In the existing pricing system, the price of China's resource-based products has been low, which seems to reduce production and daily life costs, but actually causes high energy-consuming industries to expand 
with consequences of environmental pollution, resource exhaustion. Only by lowering products prices, can state-owned enterprise controllers take kickbacks or seek rents. Sell resource-based products to someone you know at a lower price and let the agent sell it at a higher price, then State-owned enterprise controllers get the benefit. For example, as an irreplaceable resource, rare earth should not be sold at a low price, but the controllers sell and excessively export rare earths in disregard of the consequences. Second, lowering the price of financial products. For example, in the reform of state-owned enterprises, through private enterprise buying shares and $\mathrm{MBO}$, state-owned enterprise controllers try all the means to lower the stock price for their own interests, resulting in loss of state-owned assets.

3) Laying stress on scale while neglecting efficiency. Scale-up of enterprises often leads to bureaucracy, increase of management costs and inefficiency. In particular, the indicators of asset-liability ratio and ROI of some state-owned enterprises are far from the private enterprises. At the end of 2016, the asset-liability ratios of central government enterprises, local state-owned enterprises and industrial enterprises above scale were respectively $68.6 \%, 63.3 \%$ and $63.2 \%$. But why do state-owned enterprises controllers seek scale expansion and sacrifice efficiency in the name of "bigger and stronger"? Here are three reasons. First, some controllers are officials as well as businessmen, who not only pursue economic interests, but also political interests. Because of limited tenure, their political future is attached more importance than economic benefits. They gain greater political capital and political future through "benefit transfer". Second, the controllers are afraid of apparent promotion but real demotion. It shows that leadership reshuffle at state-owned enterprises is often inversely proportional to performance improvement. Take the group company as an example, the personnel change is determined to a large extent on the appointment of superior administrative departments. In the appointment system, executives with strong operation capabilities often hide their capabilities. Because if the company does well, many people are eying on the cake, and they are afraid of being kicked upstairs. Third, the national finance ensures the basic line. Facing different market players, the state sometimes has a preference for state-owned enterprises. When state-owned enterprises are supposed to be eliminated by the market because of poor management, the national financial subsidies buy them some breathing space.

\section{Consequences of Anti-Business Logic Behavior of State-Owned Enterprises Controllers}

\subsection{Severe Overcapacity}

In free competition, overcapacity is temporary, which will match the market demand in the long run and bring about optimal capacity utilization. However, due to the anti-business logic behavior of state-owned enterprises controllers, overcapacity will exist for a long time and result in production increase without 
revenue increase, or revenue increase without profits increase.

\subsection{Increasing of Zombie Companies}

Zombie enterprises refer to those enterprises that have ceased production, or have ceased production, or have suffered losses for several years, or are insolvent. They are mainly maintained by government subsidies and bank loans. Controllers' lack of cost constraints leads to high cost and long-term negative profit. Rather than improve hematopoiesis function, they are poisoned by the thoughts of waiting, relying and demanding, even consume taxes and bank deposits of taxpayers through the conspiracy between government and enterprises, enterprises and banks. In this way zombie enterprises occupy resources while fail to generate revenues [2]. The extremely asymmetry between high resource occupation and low efficiency makes zombie enterprises a burden in national economic development.

\subsection{Accelerated Loss of State-Owned Assets}

Since state-owned enterprise controllers are agents rather than owners [3], their behavior does not necessarily speak for state purpose. The controllers believe enterprises belong to the state, make profits for the state and are compensated by the state. What's more, due to limited tenure, personal interests outweigh corporate profits in their minds, hence comes anti-business logic behavior, such as non-profit-orientation, lack of cost constraints, blind investment, redundant construction, lowering prices, stressing on scale while neglecting efficiency, etc. These have caused state-owned enterprises to lose money or go bankrupt, loss of a large amount of state-owned assets which become private purses for controllers and stakeholders [4].

\section{Solutions}

To strengthen and expand state-owned enterprises, enhance the vitality, influence and risk resistance, and realize preservation and appreciation of state-owned assets, we must at first rectify the anti-business logic behavior of state-owned enterprises controllers, cultivate entrepreneurship and sense of ownership, advocate profit-oriented principle and address the issue of incentives and inefficiency in the state-owned system. This corresponds to proposal of the $19^{\text {th }} \mathrm{Na}$ tional Congress to improve various state property management systems and reform authorized operation of government capital. Secondly, measures should be taken such as stopping financial subsidies, establishing external supervision mechanisms and implementing anti-corruption to force state-owned enterprises controllers to improve management.

\subsection{Reforming the Personnel System of One-Way Promotion}

The personnel appointment at state-owned enterprise controllers is more favorable to officials who have the chances to either gain social power in government 
departments or get high salary in enterprises. However, there is expertise involved in every profession. It is impossible that officials are more adept at operation than managers in the enterprises. Therefore, to change the anti-business logic behavior of state-owned enterprise controllers, origin must be changed. The key to reforming the personnel system of one-way promotion is to appropriately separate the government from enterprise. Officials should be restricted from serving in state-owned enterprises while executives with good performances should be promoted to government department. This not only prevents officials from dominating enterprises and causing inefficiency, but also offers outstanding executives an opportunity to serve at the government and arouses their enthusiasm.

\subsection{Implementing a System of Quasi-Owner Incentives}

The key to a stronger and bigger state-owned enterprise is to motivate the human capital. However, property right of human capital belongs to the individual. Without incentives, it is not enough to give full play to human capital. It will not work in practice to let the horse run without feeding it. The state-owned enterprise is still dominated by government, which leads to the prevalence of anti-business logic behavior and lack of profitability at state-owned enterprise. Therefore, government's management philosophy of state-owned enterprises must be changed from domination to efficiency, to mobilize the enthusiasm of state-owned enterprises controllers, stimulate and protect their entrepreneurial spirit, reduce anti-business logic behavior, maximize human capital, cultivate the sense of ownership, give full play to talents, control costs, generate profits, and thus turn losses into profits and enhance the innovation and competitiveness of state-owned enterprises. Specifically, the first is to expand the autonomy in management of state-owned enterprise controllers. SASAC as a state-level agent no longer manages people, but instead manage capital; the second is to implement high annual-salary system and high-rate progressive tax system. Te controller will control the cost and shift from sales orientation to profit orientation; the third is to implement incentives system of stock option, make controllers become shareholders and share dividends. And thus the executives will have a sense of ownership and do everything they can to maintain and increase state-owned assets.

\subsection{Reducing Properly the Financial Subsidies}

"Hardship will lead to prosperity, while comfort will incur destruction." With government financial subsidies, state-owned enterprises controllers lack awareness of unexpected development, which encourages their anti-business logic behavior. In the long run, the profitable state-owned enterprises will also be slack, lack of innovation and efficiency; the unprofitable state-owned enterprises still survive relying on the government subsidies. In addition, the financial subsidies have caused unfair competition for other market players, and corruption is 
prone to occur. In order to create a fair market competition environment, improve efficiency of state-owned enterprises, reduce the state financial burden and eliminate corruption, unnecessary financial subsidies must be stopped and we must "clean up and abolish all kinds of regulations and practices that damage unified market and fair competition."

\subsection{Establishing an External Monitoring Mechanism and Implement the Anti-Corruption Policy}

A single incentive mechanism is far from enough. After all, "A man whose heart is not content is like a snake which tries to swallow an elephant," so it is necessary to establish an external supervision and punishment mechanism to correct the anti-business logic behavior. The first is to implement the system of accrediting board of supervisors. Accredited by SASAC and independent from the leadership of state-owned enterprise controllers, the board of supervisors is responsible for supervising state-owned enterprise controllers and management staff. To improve the board of supervisors, what should be done first is to speed up its organizational construction, improve the professional quality of the members and introduce more independent talents; then is to learn from foreign management systems or other successful board of supervisors, to improve the organizational status of the board, make it have more voice in management and decision-making, and ensure the independence of the board; finally, increase the participation of the board of supervisors in business to have a full understanding of business information. The second is to implement the anti-corruption policy. It is the anti-business logic behavior of state-owned enterprises controllers and integration of government administration with enterprise that lead to corruption and loss of state-owned assets in state-owned enterprises. A good platform for wealth creation has deteriorated to a hotbed of corruption and exorbitant profits. The realization of enterprise goals is hindered, and reform measures are ineffective in a long term, resulting in loss of confidence in the reform among employees and neglect of errors. If left unchecked, it will inevitably cause the state-owned enterprises reform to become ostrich policy and affect the healthy development of the state-owned economy. In the report of the $19^{\text {th }}$ National Congress, General Secretary Xi Jinping proposed that a normal state of "stressing on restraint, high-pressure and long-term deterrence" in anti-corruption should be formed and "creating a honest and upright environment by unremitting efforts." Therefore, it is imperative that we pay close attention to anti-corruption in state-owned enterprises and reduce the losses caused by corruption.

\section{Conclusion}

This paper mainly focuses on the anti-business logic behavior of the state-owned enterprise controller. It analyzes the causes and possible consequences, and finally proposes some solutions. The core value of this paper is to point out the harm of this behavior, remind the government to keep paying attention, and lay 
a foundation for the government to introduce relevant management system and avoid this bad behavior. To sum up, only by implementing both incentive mechanism and restraint mechanism of "adhering to strict management and kindness, equally stressing on encouragement and restraint" can the anti-business logic behavior of state-owned enterprises controllers be corrected. Only by seizing the critical minority and guided by profit maximization, can state-owned enterprises be transformed from administrative subordinate to producers and operators of self-employment, self-financing, self-discipline and self-development, can the market attributes of state-owned enterprises be triggered, and can the efficiency of resource allocation be improved to truly bring benefits to the state and the people.

\section{Conflicts of Interest}

The authors declare no conflicts of interest regarding the publication of this paper.

\section{References}

[1] Gao, H.Y. (2006) Western Economics (Micro Part). 4th Edition). Renmin University of China Press, Beijing, 124.

[2] Qi, Q.H. (2016) The Death of Zombie Companies. China Business News, Beijing.

[3] Yuan, Z.G. (1995) Some Thoughts on the Loss of State-Owned Assets. Economic Research Journal, No. 4, 37-41.

[4] Li, J. (2002) Thoughts on the Loss of State-owned Assets in China during Economic Transition. Journal of South China Tropical Agriculture University, No. 9, 38-45. 